\title{
ANALISIS MANAJEMEN RISIKO PEMBIAYAAN DAN PENGELOLAAN PRODUK PPR IB MASLAHAH DI BJB SYARIAH KCP. KUNINGAN
}

\author{
Faiz Raka Alfarizi ${ }^{1}$, Qiny Shonia Az Zahra ${ }^{2}$
}

${ }^{1}$ Program Studi Ekonomi Syariah, Universitas Siliwangi, faizraka98@ gmail.com

${ }^{2}$ Program Studi Ekonomi Syariah, Universitas Siliwangi, qiny@unsil.ac.id

\begin{abstract}
Housing is one of the basic human needs. Meanwhile, in fact, from the data on the number of Sharia mortgage customers at Bank Jabar Syariah, namely the PPR IB Maslahah product for the 2017-2020 period, it fluctuated and tend to decrease. In addition, it needs a good financing risk management implemented by the company. The objective of this research is to find out how the risk management of financing and product management of PPR IB Maslahah Bank BJB Syariah KCP Kuningan. This study uses premier data from interviews conducted to several employees of Bank BJB Syariah KCP Kuningan, by triangulation technique. Meanshile, the results of this study are:1). The financing risk management carried out by Bank BJB Syariah is in accordance with the Financial Services Authority Regulation (POJK) Number 65 / POJK.03 / 2016 concerning the Implementation of Risk Management for Sharia Commercial Banks and Sharia Business Units as stated in article 3 in point c; 2) Management of PPR Products carried out by Bank BJB Syariah Kuningan has been implemented, however in fact they have limited authority from the headquarters.
\end{abstract}

Keywords: Risk Management, Financing, Product Management, PPR IB Maslahah

\begin{abstract}
ABSTRAK
Rumah merupakan salah satu kebutuhan pokok manusia. Sedangkan pada faktanya, dari data jumlah nasabah KPR Syariah di Bank Jabar Syariah, yakni dengan produk PPR IB Maslahah periode 2017-2020 mengalami fluktuasi dan cenderung mengalami penurunan. Dalam menjalankan pembiayaan KPR,perlu adanya Manajemen Risiko yang baik dalam penerapannya di perusahaan.Penelitian yang ini bertujuan untuk mengetahui bagaimana manajemen risiko pembiayaan dan pengelolaan produk pada PPR IB Maslahah. Penelitian ini menggunakan data primer dari hasil wawancara kepada beberapa pegawai Bank BJB Syariah KCP Kuningan. Teknik pengumpulan data menggunakan triangulasi. Penelitian ini mengungkapkan mengenai:1). Manajemen risiko pembiayaan yang dilakukan oleh Bank BJB Syariah sesuai dengan Peraturan Otoritas Jasa Keuangan (POJK) Nomor 65/POJK.03/2016 Tentang Penerapan Manajemen Risiko Bagi Bank Umum Syariah Dan Unit Usaha Syariah yang tertera pada pasal 3 pada poin c; 2) Pengelolaan Produk PPR yang dilakukan oleh Bank BJB Syariah Kuningan sudah dilakukan tetapi ada keterbatasan karena perlu otoritas dari kantor pusat.
\end{abstract}

Kata Kunci: Manajemen Risiko, Pembiayaan, Pengelolaan Produk, PPR IB Maslahah

\section{PENDAHULUAN}

Banyaknya masyarakat yang berpendapat bahwa dengan menggunakan jasa bank akan membebani dengan bunga yang kadang naik dan tidak menentu, Perbankan syariah mengeluarkan produk berupa KPR Syariah bertujuan tidak membebani masyarakat atas riba 
dalam memenuhi kebutuhan masyarakat atas kepemilikan rumah. Ada letak perbedaan prinsip pada kedua system perbankan tersebut di mana Perbankan syariah memiliki konsep bagi hasil dan kerugian (Profit and loss sharing). Selain itu jika ditinjau dari produknya, nilai plus lainnya dari Perbankan Syariah mempunyai kelebihan dan memiliki segmentasi pasar tersendiri, yakni para nasabah muslim yang sudah percaya bahwa KPR Syariah berlandaskan syariat islam, tidak mengandung unsur-unsur yang diharamkan seperti Maishir, Gharar dan Riba. Meskipun begitu, risiko bagi pihak perbankan syariah tetap ada, berbanding lurus dengan kualitas atau manajemen risiko pembiayaan yang diimplementasikan oleh pihak perbankan. Jika implementasi manajemen risikonya baik, maka risiko akan adanya kerugian bisa diminimalisir. Sehingga bank syariah tersebut bisa memiliki daya saing di tengah banyaknya perusahaan yang menawarkan pembiayaan atau produk yang sejenis, tidak hanya bank syariah tetapi juga bank konvensional.

Selain itu akan ada risiko yang yang muncul dan dihadapi juga memiliki efek yang bisa mempengaruhi kestabilan lembaga keuangan karena risiko sendiri, yang menjadi konsukensi yang disebabkan oleh pengambilan keputusan di tengah adanya ketidakpastian. Hal tersebut memiliki kemungkinan dengan adanya hasil yang kurang diharapkan atau dampak kurang baik lainya yang merugikan bagi para pengambil keputusan. (Imam, 2003: 4). Seperti risiko nasabah yang gagal bayar atau memenuhi kewajiban tepat pada waktunya. Risiko memiliki beberapa variabel atau dimensi seperti biaya peluang, potensi kerugian atau dampak kurang baik lainya, maka berdasarkan hal dari berbagai dimensi tersebut setidaknya risiko bisa diukur dan dipantau selama proses berjalan.

\section{Grafik 1. Produk KPR Syariah di BI - Triwulan 2018}

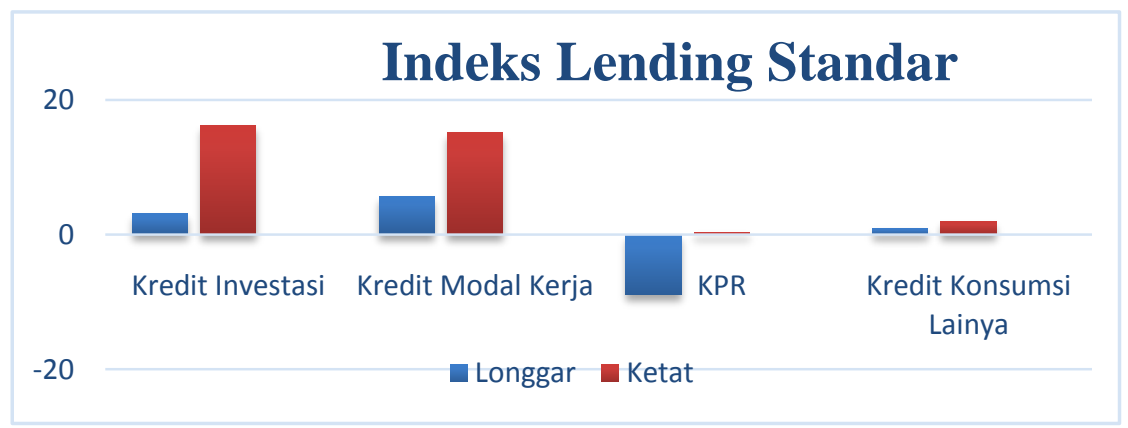

(Sumber :www.bi.go.id )

Dari gambar diatas tahun 2018 dapat dilihat bahwa grafik KPR mengalami kelonggaran ini disebabkan oleh beberapa keputusan yang diambil oleh setiap Perbankan Received: March 12, 2021| Accepted: September 25, 2021| Published: November 22, 2021 
Syariah terutama dalam pembiayaan KPR, kedepan akan menjadi momentum ketika bonus demografi apakah sesuai dengan kebutuhan manusia untuk bertahan hidup, karena semakin banyaknya populasi manusia di bumi. Jenis pembiayaan yang disalurkan oleh Bank BJB Syariah KCP Kuningan sebagian besar menggunakan akad mudharabah, murabahah, istishna,wadiah, qardh. Untuk kepemilikan rumah biasanya menggunakan akad murabahah dan istishna, ada pengkhususan juga ketika terjadi pembelian secara cash atau kredit maka akadnya berbeda.

Tabel mengenai Nasabah PPR IB Maslahah di Bank BJB Syariah Kuningan pada tiga tahun terakhir :

Tabel 1.1

Data Nasabah PPR IB Maslahah BJB Syariah KCP Kuningan

\begin{tabular}{|r|c|}
\hline Tahun Pembiayaan & Jumlah Nasabah \\
\hline 2017 & 22 \\
\hline 2018 & 19 \\
\hline 2019 & 20 \\
\hline 2020 & 6 \\
\hline JUMLAH & 67 \\
\hline
\end{tabular}

(Sumber data : Hasil wawancara dengan CS)

Dilihat dari data tabel tersebut adanya fluktuasi jumlah nasabah dari tahun 2017 sampai 2020 yang cenderung mengalami penurunan. Bahkan pada tahun 2020, jumlah nasabah PPR iB Maslahah ini hanya 6 orang. Penurunannya cukup drastis disbanding beberapa tahun sebelumnya, meskipun di tengah pandemi. Berdasarkan pemaparan latar belakang permasalahan di atas, maka penulis mencoba melakukan penelitian mengenai Analisis Manajemen Risiko Pembiayaan dan Pengelolaan Produk PPR IB Maslahah di BJB Syariah KCP Kuningan.

\section{LITERATUR REVIEW}

\section{Pengertian Risiko}

Risiko banyak ditemukan dalam setiap aspek kehidupan manusia dari individu sampai kelompok atau perusahaan, termasuk dalam kehidupan sehari-hari misalkan risiko dari gaya hidup seperti makanan dan pola istirahat. Istilah risiko dalam Bahasa arabata مجازa secara istilah استمات - يستميت. ${ }^{2}$ Philip Best mengemukakan bahwa risiko merupakan kerugian secara finansial, baik secara langsung maupun tidak langsung. Sedangkan risiko dalam perbankan 
adalah kemungkinan untuk mengalami kerugian (exposure to the change of loss). Menurut Peraturan Bank Indonesia (PBI) (2009), risiko bisnis bank adalah risiko yang berkaitan dengan pengelolaan usaha bank sebagai perantaraan keuangan.

\section{Jenis-Jenis Risiko}

Dalam Peraturan yang dikeluarkan oleh Bank Indonesia nomor 13/23/PBI/2011 (2011) mengenai penerapan manajemen risiko bagi Bank Umum Syariah dan Unit Usaha Syariah terdapat sepuluh jenis risko yang dihadapi bank syariah, Delapan risiko pertama merupakan risiko umum yang berimplikasi pada perbankan lainnya selain bank syariah. Risiko tersebut, yakni: Pertama, Risiko Kredit; Kedua, Risiko Pasar; Ketiga, Risiko Likuiditas, Keempat Risiko Operasional; Kelima, Risiko Hukum; Keenam Risiko Reputasi; Ketujuh Risiko Strategis; Kedelapan Risiko Kepatuhan; Kesembilan, Risiko Imbal Hasil (Rate of Retrun Risk); Kesepuluh atau yang terakhir adalah Risiko Investasi.

\section{Proses Manajemen Risiko}

Menurut Idroes, (2011: 7) Proses manajemen risiko merupakan aktivitas dari seluruh pihak terlibat di dalam organisasi. Semua aspek dan stakeholder terkait harus ikut serta dalam proses ini supaya implementasi manajemen risiko tercapai. Sehingga risiko bisa diminimalisir, menghindari kerugian yang lebh besar. Berikut adalah tahapan proses manajemen risiko yang perlu dilakukan suatu organisasi, lembaga atau perusahaan.

1) Identifikasi Risiko

Identifikasi menjadi tahapan yang pertama dalam kaitannya dengan proses risiko. Dalam proses ini, pelaksanannya menerapkan beberapa prinsip yang harus diutamakan dan dipegang terkait mengenali kemungkinan-kemungkinan risiko yang bisa ditemui. Yakni, prinsip 5C (Character, Capacity, Capital, Collateral,Condotions). Selain itu juga dilihat dari SLIK, untuk mengidentifikasi apakah calon nasabah ini jika tiba saatnya melakukan pembayaran angsuran atas pembiayaan ini tepat pada waktunya atau tidak.

\section{2) Pengukuran Risiko}

Tahapan kedua dalam proses risiko adalah pengukuran risiko. Risiko perlu diukur, sejauh mana risiko yang bisa ditimbulkan atau tidak, supaya bisa segera disiapkan alternative atau solusi atas risiko tersebut. Pada tahapan ini, dilakukan sebagai pedoman dan dasar dalam memahami sejauh mana risiko tersebut berpengaruh dari kerugian yang bisa terjadi atas timbulnya risiko, baik secara individual maupun portofolio, terhadap tingkat likuiditas 
perusahan dan sejauh mana perusahaan tersebut bisa bertahan atau sustain. (Rivai dkk, 2013:133).

\section{3) Pemantauan Risiko}

Selanjutnya, setelah menerapkan pengukuran risiko, yang perlu dilakukan adalah memantau, mengawasi supaya bisa menjadi bahan evaluasi bagi kemungkinan risiko yang bisa terjadi. Sesuai dengan fungsi dasar menajemen, yakni perlunya pengawasan atau pemantauan dalam proses operasional perusahaan, begitupun dalam manajemen risiko. Pemantauan atau pengawasan tersebut dilakukan oleh pihak perusahaan sehingga bisa terkendali untuk mencegah kerugian yang mungkin terjadi.

4) Pengendalian Risiko

Dalam langkah terakhir, perlu adanya pengendalian atas tahapan sebelumnya. Pengendalian atau controlling juga bagian dari fungsi manajemen yang sangat penting untuk diimplementasikan dalam manajemen perusahaan, termasuk dalam manajemen risiko. Selain untuk menghindari risiko yang lebih besar, adanya controlling bisa meminimalisir risiko yang akan ditimbulkan. Karena risiko tidak bisa dihindari, tetapi bisa diminimalisir.

\section{Pengertian Pembiayaan}

Pembiayaan atau financing adalah proses penyaluran dana yang disalurkan oleh suatu pihak kepada pihak lainnya untuk mendukung investasi yang telah direncanakan, baik dilakukan sendiri maupun lembaga. Dengan kata lain pembiayaan adalah pendanaan yang dikeluarkan untuk mendukung investasi yang telah direncanakan.Pembiayaan merupakan bagian dari fngsi intermediasi perbankan, di mana pihak yang mempunyai kelebihan dana menyimpan dananya di bank berupa tabungan, deposito, dll, dengan pihak yang memiliki kekurang dana, dengan ini adalah produk pembiayaan. Sedangkan menurut Kasmir (2002: 325) penyediaan uang, dana atau tagihan yang dapat dipersamakan dengan itu, berdasarkan persetujuan atau kesepakatan antara bank dengan pihak nasabah yang mewajibkan pihak yang dibiayai untuk mengembalikan uang atau tagihan tersebut setelah periode tertentu dengan bagi hasil yang telah disepakati.

\section{Tujuan Pembiayaan}

Tujuan pembiayaan berdasarkan prinsip syariah untuk mendapatkan keberkahan dan kesejahteraan ekonomi sesuai dengan syariah yang berlandaskan Al-Quran, Al-hadits, Ijma dan Qiyas. Artinya, proses pembiayaan dalam suatu bank harus sesuai dengan prinsip prinsip syariah. Tidak hanya di bidang industry berupa barang, tetapi pembiayaan bisa dimanfaatkan 
atau dilakukan oleh para pemilik usaha atau perusahaan di berbagai bidang yang sesuai azas syariah, seperti bidang perdagangan atau pertanian juga di industry dengan output berupa jasa serta kaitannya dengan distribusi barang dan jasa (Yusuf dkk, 2009: 68).

\section{Pembiayaan yang digunakan}

1) Murabahah

Secara bahasa, kata murabahah berasal dari bahasa Arab dengan akar kata ribh yang artinya keuntungan. Sedangkan secara istilah, menurut Hakim (2012: 116), murabahah adalah akad jual beli terkait suatu barang, dimana penjual menyebutkan harga jual yang terdiri atas harga pokok produk disertai dengan tingkat profit tertentu atas suatu barang tersebut, sesuai dengan persetujuan pembeli.

Landasan mengenai murabahah dalam Al-quran terdapat pada Q.S Al-Baqarah ayat 275 sebagaimana berikut :

$$
\text { وا حل اللة البيع و حر م الر بوآة }
$$

Artinya : Dan Allah telah menghalalkan jual beli dan mengharamkan riba (AlBaqarah;2:275)

Secara sederhana, Karim (2011: 113) mengemukakan murabahah berarti suatu aktivitas menjual produk dengan nilai yang sama atas barang tersebut ditambah dengan keuntungansesuai kesepakatan. Contohnya adalah produk yang dia beli dijual kembali dengan pengambilan untung sesuai dengan kesepakatan, apakah dengan satuan harga ataupun presentasi contohnya adalah sebesar lima belas persen. UU No.21 Tahun 2008 tentang Perbankan Syariah, menjelaskan bahwa yang dimaksud dengan murabahah adalah akad pembayaran suatu barang dengan menegaskan harga belinya kepada pembeli dan pembeli membayarnya dengan harga yang lebih sebagai keuntungan yang disepakati (UU Perbankan Syariah, 2008)

Dalam fatwa DSN (Dewan Syariah Nasional) No 04/DSNMUI/IV/2000 tentang pembiayaan murabahah, dijelaskan bahwa yang dimaksud dengan murabahah yaitu menjual suatu barang dengan menegaskan harga belinya kepada pembeli, dan pembeli membayarnya dengan harga yang lebih sebagai laba.

2) Istishna'

Istishna adalah aktivitas dengan proses pemesanan kepada perusahaan untuk memproduksi barang atau komoditas tertentu untuk pembeli atau pemesan (Ascarya, : 2008:96). 
Dalam fatwa DSN-MUI, dijelaskan bahwa jual beli istishna' adalah akad jual beli dalam bentuk pemesanan pembuatan barang tertentu dengan kriteria dan persyaratan tertentu yang disepakati antara pemesan (pembeli, mustashni') dan penjual (pembuat, shani') (Karim, 2011:126).

Landasan Al-Quran megenai istishna ada dalam Qs Al-Baqarah ayat 282 seperti dibawah ini.

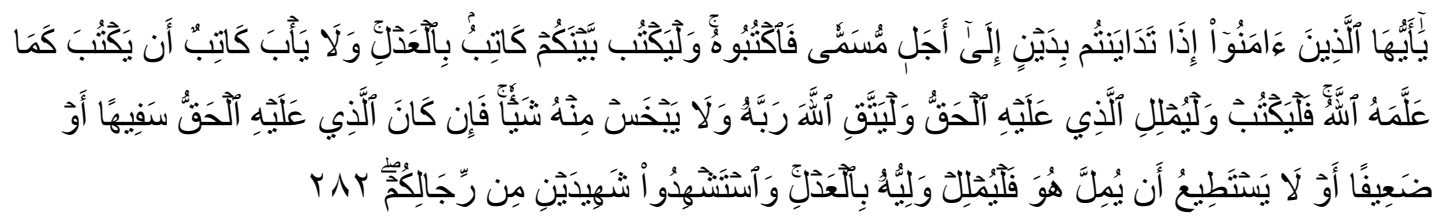

"Hai orang-orang yang beriman, apabila kamu bermu'amalah tidak secara tunai untuk waktu yang ditentukan, hendaklah kamu menuliskannya. Dan hendaklah seorang penulis di antara kamu menuliskannya dengan benar. Dan janganlah penulis enggan menuliskannya sebagaimana Allah mengajarkannya, maka hendaklah ia menulis, dan hendaklah orang yang berhutang itu mengimlakkan (apayang akan ditulis itu), dan hendaklah ia bertakwa kepada Allah Tuhannya, dan janganlah ia mengurangi sedikitpun daripada hutangnya..."

\section{Pengertian Pengelolaan}

Menurut Arikunta (1988:8),pengelolaan adalah kata benda dari manajemen, sedangkan manajemen berarti tindakan yang dimulai dengan penyusunan data, perencanaan, pengorganisasian, pelaksanaan,pemantauan danevaluasi. Adanya pengolaan berdampak pada kualitas manajemen perusahaan baik di masa sekarang maupun di masa depan.

Sedangkan, Mary Parker Follet mengemukakan pengelolaan adalah seni atau proses menyelesaikan tugas yang berhubungan dengan pencapaian tujuan. Tiga faktor yang memiliki pengaruh dalam proses ini yaitu:

1) Penggunaan sumber daya organisasi yang baik dalam produksi atau operasional perusahaan atau sumber daya manusia.

2) Proses ini dilakukan tahap demi tahap mulai sesuai fungsi manajemen yakni (POAC) atau planning, organizing, actuating dan controlling.

3) Kreativitas di tempat kerja (Sule dkk, 2009:6) baik dalam aktivitas dalam operasional perusahaan, juga dalam proses pengambilan keputusan serta memberikan alternative solusi atas masalah yang timbul dalam pelaksanaanya.

\section{Fungsi pengelolaan}

Ada banyak teori tentang fungsi pengelolaan/manajemen, berikut adalah fungsinya:

1) Perencanaan 
Perencanaan adalah pemilihan dan asosiasi fakta, memperkuat hipotesis tentang masa depan dengan mempertimbangkan dan merumuskan kegiatan yang diusulkan dan benar-benar diperlukan untuk mencapai tujuan. hasil yang dharapkan (Terry, 2006:46).

2) Pengorganisasian (Organization)

Dalam pengorganisasian, perusahaan focus pada pengaturan sumber daya yang dimiliki organisasi, termasuk SDM sesuai dengan tugas dan kompetensinya karena merupakan salah satu asset perusahaan dan komponen penting dalam berjalannya perusahaan tersebut untuk mencapai tujuan perusahaan.

3) Pergerakan (Actuating)

Actuatingdalam Susilo (1988:86) merupakan suatu serangkaian kegiatan yang dilakukan oleh seorang pemimpin untuk memulai dan melanjutkan kegiatan yang ditentukan oleh faktor perencanaan dan pengorganisasian sehingga tujuan dapat dicapai.

4) Pengawasan (controlling)

Pengawasan adalah kegiatan yang terdiri dari pemeriksaan bahwa segala sesuatu berjalan sesuai dengan rencana yang ditetapkan atau tidak, apakah instruksi yang diberikan sesuai atau tidak dengan prinsip yang disepakati (Syafri, 1996:42). Pemantauan terdiri dari verifikasi bahwa segala sesuatu berjalan sesuai dengan rencana yang ditetapkan atau tidak, apakah instruksi yang diberikan sesuai atau tidak dengan prinsip yang disepakati.menugaskan tugas-tugas ini kepada orang-orang/ SDM sesuai dengan kemampuan mereka dan mengoordinasikan mereka untuk mencapai tujuan organisasi secara efektif.

\section{Pengertian Produk PPR IB Maslahah}

Pembiayaan Pemilikan Rumah (PPR) IB Maslahah merupakan salah satu produk pembiayaan dari BJB Syariah. Produk ini termasuk Fasilitas Pembiayaan yang diberikan kepada perorangan untuk membeli, membangun dan atau renovasi rumah atau hunian (termasuk ruko, rukan, apartemen dan sejenisnya). Pembiayaan PPR iB Maslahah dalam praktiknya menggunakan dua akad, yakni mudharabah dan istishna.

\section{METODE PENELITIAN}

Dalam prosesnya, penelitian ini menggunakan metode deskriptif kualitatif. Peneliti menggunakan sumber data primer yakni Customer Service (CS), Analis dan Salesman Bank BJB Syariah KCP Kuningan. Adapun sumber data lainnya dalam penelitian ini berupa dokumen print Bank BJB Syariah KCP Kuningan. Teknik pengumpulan data yang dilakukan 
dengan interview (wawancara) dan observasi (pengamatan). Uji kredibilitas yaitu kepercayaan terhadap data hasil penelitian kualitatif, dilakukan dengan cara Triangulasi dan menggunakan referensi (Sugiyono, 2010:270). Sedangkan langkah analisis data yaitu Data Reduction (Reduksi Data), Data Display (Penyajian Data), dan Conclusion Drawing/Verification.

\section{HASIL DAN PEMBAHASAN}

\section{Analisis Manajemen Risiko Pembiayaan}

Dalam melakukan manajemen risiko ada berapa bagian yang harus dilalui dalam memudahkan proses diantaranya yaitu :

1) Identifikasi Risiko

Proses pembiayaan di bank dilakukan guna untuk terjadinya perputaran uang sehingga lembaga keuangan bisa tetap berjalan, lalu seperti apa proses identifikasi yang dilakukan bank BJB Syariah terhadap nasabah yang melakukan pengajuan pembiayaan, penerapan prinsip 5C (Character, Capacity, Capital. Collateral, Conditions) dalam proses pengajuan pembiayaan menjadi poin utama guna nasabah layak atau tidaknya diterima dalam pengajuan pembiayaan.

Character,menjadi analisa pertama yang sangat menentukan layak atau tidaknya diberikan pembiayaan, pengecekan awal dilakukan melalui SLIK (Sistem Layanan Informasi keuangan) dan Daftar Hitam Nasional atau biasa disebut blacklist. Slik merupakan sistem informasi yang pengelolaanya dibawah tanggung jawab OJK dengan tujuan melaksanakan tugas pengawasan dan pelayanan informasi keuangan salah satunya informasi debitur. Sedangkan Daftar Hitam Nasional merupakan suatu upaya yang dilakukan oleh Bank Indonesia untuk mencegah peredaran cek atau bilyet giro kosong.

Sesuai dengan aturan Bank Indonesia Nomor 8/29/PBI/2006 apabila pihak yang memberikan cek kosong akan dikenakan sanksi yaitu dimasukan kedalam daftar hitam nasional. Selain itu, penilaian poin character adalah melalui SPPT pajak dan rekening listrik calon nasabah. Hal ini terkait kemampuan calon nasabah dalam memenuhi kewajibannya, apakah tepat waktu atau tidak. Apakah ada tunggakan pada sekian waktu atau periode tertentu sehingga hal tersebut bisa menjadi salah satu pertimbangan ajuan KPR Syariah ini diterima.Sedangkan, jika yang mengajukan pembiayaan seorang pelaku usaha maka biasanya dilakukan pengecekan melalui supplier. Dalam kaitannya dengan supplier, melihat data 
historis mengenai kelancaran transaksi yang dilakukan pelaku usaha dengan supplier, apakah bermasalah atau sebaliknya.

Capacity, setelah melihat rekam jejak seorang nasabah melalui informasi yang di dapat selanjutnya menganalisa kapasitas nasabah dalam kemampuan membayar, dilihat dari berbagai aspek mulai dari aset yang dimiliki, atau jika calon nasabah adalah seorang karyawan atau pegawai suatu lembaga atau perusahaan, maka dilakukan pencarian informasi di tempat bekerja. Selain itu, mitigasi dilakukan terhadap warga sekitar yang tahu kondisi seorang nasabah tersebut (AO, wawancara, 23 Maret 2021).

Jika AO menilai capacity seorang calon nasabah dilihat dari pekerjaannya, contohnya seorang karyawan, tahapanya adalah menganalisa dari rekening koran dan payroll dan slip gaji selama tiga bulan. Kemudian, AO akan melakukan survei kepada perusahaan terkait melalui bendahara perusahaan atau pemimpin perusahaanya. Namun, berbeda jika ketika calon nasabah yang mengajukan pembiaayaan ini bukan seorang karyawan, tetapi seorang praktisi atau mempunyai pekerjaan di bidang jasa dengan membuka praktek sesuai dengan bidang ilmu atau keahliannya, seperti dokter, notaris, arsitek, bidan dsb, maka rekening koran yang di tampilkan atau dilampirkan untuk menjadi bagian dari proses analisis adalah minimal dalam waktu satu tahun. Jika ada yang bermasalah terkait data atau informasi tersebut, maka dalam tahapan ini calon nasabah tidak layak untuk diberikan pembiayaan.

Capital, yakni ditinjau dari segi modal yang dimiliki seorang calon nasabah. Jika calon nasabah yang mengajukan pembiayaan adalah seorang entrepreneur yang memiliki perusahaan sendiri, atau justru berupa badan perusahaan, maka capital yang ditinjau adalah dari mulai analisis akta perusahaan. Selain itu, pihak bank yakni AO akan menganalisa dari profil perusahaan dan laporan keuangan apakah perusahaan ini cash flownya lancar, atau justru sebaliknya karena sedang berada dalam kondisi yangburuk atau hampir pailit. Selain dari hal tersebut, dalam menganalisis capital biasanya para karyawan bertanya mengenai keadaan nasabah tersebut melalui oraang-orang atau karyawan yang ada di perusahaan tersebut. Jika nasabah bukan berupa perusahaan atau badan usaha, analisis dilakukan kepada orang terdekat seperti keluarga atau rekan bisnis. Tetapi, biasanya analisis atau identifikasi risiko dalam tahapan capital lebih banyak dianalisa ketika nasabah melakukan pembiayaan produktif, yakni pembiayaan yang digunakan untuk berwirausaha atau menambah modal perusahaan. 
Collateral, berupa menjadi jaminan yang diberikan calon nasabah saat mengajukan pembiayaan, disebut juga agunan. Jaminan yang termasuk sebagai syarat pembiayaan PPR Syariah bisa berupa barang bergerak, atau barang diam atau aset tetap dan aset bergerak. Aset tersebut juga harus memenuhi kriteria yang sudah disepakati bank dilihat dari harga pasar dan nilai likuidasi, jika mampu menutupi nominal dari jumlah pembiayaan yang diajukan, maka bisa diterima. Jika setalah ditinjau dan dianalisis berdasarkan perhitungan nilai asetnya ini dirasa kurang, maka pihak bankakan meminta aset yang nilainya lebih besar dari asset yang ditawarkan untuk menjadi jaminan sebelumnya, sehingga nilai jaminan atau asset tersebut menutupi atau melebihi dari nilai pembiayaan yang diajukan calon nasabah kepada pihak bank.

Jika PPR itu diperuntukan pembangunan bisa memakai akad istishna dan murabahah, istishna bisa dilakukan ketika rumah tersebut dipesan secara indent, sedangkan murabahah untuk renovasi. Mitigasi risko yang dilakukan leawat financing to value yaitu besar pembiayaan terhadap nilai aset, atau nilai harga objek yang dibiayai, financing to value bank yang diterapkan $80 \%$ dari harga pasar atau harga penawaran, jadi mencairkan harga itu tidak $100 \%$ collateral. Jika yang dilakukan dengan renovasi terhadap rumah bersubsidi, hal ini akan berbeda maka yang diberikan nilainya sejumlah transaksi awal atau 50\% sesuai harga pembelian, kemudian bisa mencairkan lagi ketika progress pembangunan signifikan dan proses pembayaran lancar. Nilai Hak Tanggungan merupakan seberapa besar nilai untuk menanggung apakah bisa menutupi atau tidak, dikhawatirkan nasabah mengalami oneprestsi maka dijual oleh pihak nasabah.

Conditions, Keadaan atau kondisi objektif yang dialami seorang nasabah baik dari segi psikologi, keluarga, ekonomi dan sebagainya. Selain dari kondisi ekonomi, yakni ada potensi calon nasabah tersebut mampu memenuhi kewajibannya secara tepat waktu, juga setelah meninjau dan menganalisis dari berbagai tahapan sebelumnya, atau dari sikap, sifat, dan karakter nasabah, kondisi keluarga juga menjadi poin penting dalam pertimbangan pengajuan pembiayaan PPR iB Maslahah. Keadaan keluarga yang tidak harmonis juga bisa menjadi tambahan nilai untuk dipertimbangan dan kemungkinan besar pengajuan pembiayaanya tidak diterima, karena bisa berakibat pada risiko yang akan ditimbulkan ketika nasabah tersebut mengalami gagal bayar atau melunasi pembiayaan. Ditinjau dari masalah tersebut, risiko yang bisa diminimalisir adalah adanya kemungkinan akan sulit menghubungi 
orang terdekat. Pada kasus yang lebih buruknya lagi, bahkan orang terdekatnya tidak mau ikut campur terhadap hal tersebut sehingga bisa terjadi gagal bayar.

Selain itu, dengan melihat kondisi sekarang, saat sedang adanya pandemi banyak perusahaan yang melakukan merumahkan karyawan (PHK). Tidak hanya PHK,tetapi sebagian juga ada yang merumahkan sementara, artinya mereka berhenti bekerja atau diliburkan sementara karena perusahaan tersebut tidak memiliki dana yang cukup untuk menggaji para karyawannya bahkan akan dikhawatirkan perusahaan tersebut tidak bisa survive.

Produk PPR Bank BJB Syariah memilik perbedaan yang terletak pada aturan margins yang ditentukan oleh pihak bank lebih minimum, kasus yang terjadi dalam pembiayaan PPR lebih dominan oleh kelas pekerja swasta/karyawan perusahaan, beberapa lembaga yang sudah bekerja sama diantaranya, STKIP Muhammadiyah Kuningan, RS Juanda, Pondok Pesantren AlMutazam, Universitas Kuningan dan STIKES Muhammadiyah Kuningan.

\section{2) Pengukuran Risiko}

Dalam pembiayaan PPR ada proses pengukuran yang harus dilalui yaitu appraisal, tahapan ini dilakukan oleh pihak bank dengan tujuan sebagai bukti nyata bangunan yang ada dilapangan. Selain Appraisal yang menjadi pengukur ada Faktor faktor yang mendukung dalam tahapan ini yaitu kelancaran nasbaah dalam melakukan pembayaran Pajak Bumi dan Bangunan dan Listrik, serta kondisi bangunan yang masih bagus atau tidak ketika dibandingkan dengan kondisi sekitar, selain itu fasilitas dari isi rumah yang juga bernilai juga menambah value lebihdalam tahapan ini. Pengukuran risiko yang dilakukan oleh BJB Syariah KCP Kuningan yaitu dengan mengukur penaksiran dari rumah jaminan atau tanah kavling dengan tingkat kemungkinan besar, dilakukan oleh pihak APBL yang didatangkan dari Bank BJB Syariah Cabang Cirebon.

\section{3) Pemantauan Risiko}

Ketika sudah beres pembiayaan maka ada proses atau tahap pemantauan, biasanya diberlakukan untuk pembelian, pemantuan yang dilakukan tidak sering, jika pembiayaan yang bentuknya jenis lain (produktif) biasanya pemantuan dilakukan melalui pihak ketiga lewat notaris. Kunjungan terkait pengelolaan produk dari Bank terhadap nasabah, biasanya dilakukan dalam beberapa waktu jangka waktunya ada yang 7 hari, 10 hari dan 30 hari lewat telpon dan setelah tempo maka ada tambahan 10 hari, setelah itu masih menunggak maka ada Surat Peringatan 1, rentan waktu ke Surat Peringatan 3 sekitar 60 hari. Dalam penagihan 
juga dilakukan dengan waktu yang sama, dan diberikan peringatan terhadap nasabah. pemantauan dilakukan oleh BJB Syariah KCP Kuningan dengan pengecekan terhadap kondisi nasabah baik secara langsung maupun melalui telepon, serta memantau kondisi ekonomi para nasabah dalam melakukan pembayaran pembiayaan dengan kunjungan oleh pihak bank terhadap nasabah. Selain itu, dilakukan juga pengecekan melalui notaris terkait sertifikat tanah dan sebagainya.

\section{4) Pengendalian Risiko}

Dalam melakukan pengendalian risiko di Bank maka akan muncul Risk Uncontrolled atau meminimalisasi, dalam hal ini dinamakan Post Marger,yaitukejadian tak terduga yang tidak bisa terprediksi, misalkan gempa bumi, longsor dan banjir, maka kebijakan yang dikeluarkan atau pengendalian yang terjadi yaitu, dihapusnya dari buku transaksi, karena nasabah dan lembaga bank dirugikan dua-duanya. Hapus buku merupakan tindakan tidak dicatatnya pembiayaan dalam pembukuan oleh pihak bank ini terjadi ketika nasabah tidak bisa membayar, risikonya modal bank terambil.

Setelah dilakukan identifikasi ternyata terdapat beberapa risiko yang muncul terkait pembiayaan PPR yang diajukan oleh nasabah dan suadah diterima, diantaranya yaitu proses pembiayaan hingga tahapan penagihan terdapat beberapa masalah dari dokumen yang dilampirkan hingga ketelitian objek nasabah yang mengajukan pembiayaan. Risiko pembiayaan yang terjadi bisa teratasi contoh yang terjadi ketika pengendalian risiko dan dihadapakan PPR dengan bencana alam yang terjadi, maka pihak bank melakukan likuidasi dan pengahapusan buku transaksi.

Selanjutnya, dalam menghadapi nasabah yang macet pasca melakukan pembiayaan PPR, tahap awal yakni reminder melalui telepon dan chatting via instan messenger seperti WA, ketika dalam jangka waktu yang ditentukan masih ada penunggakan maka dilakukan surat pemberitahuan tunggakan, isinya pemberitahuan waktu tunggakan, setelah itu tenggang waktu 30 hari ke Surat Peringatan 1 sampai 3, bisa disebut kategori macet ketika sudah 1 tahun, maka dilakukan pelelangan jaminan yang sebelumnya sudah disertakan pada saat akad.

\section{Analisis Pengelolaan Produk PPR IB Maslahah BJB Syariah KCP Kuningan}

Beberapa tahapan pengelolaan produk yang dilakukan oleh BJB Syariah KCP Kuningan yaikni sebagai berikut : 


\section{1) Sumber daya organisasi yang baik}

Dalam tahapan pengelolaan produk memaksimalkan Sumber Daya Organisasi bisa menjadi penunjang, dan asset yang dimiliki perusahaan menjadi kunci untuk mencapai tujuan perusahaan, peranan sumber daya manusia yang dimiliki oleh BJB Syariah KCP Kuningan juga menjadi sangat penting, ketika terjadi suatu risiko dari produk maka SDM yang baik akan memberikan ide dan solusi yang jelas serta konkrit, sehingga membantu pihak bank dalam memberikan jalan keluar, maka SDM yang baik dan memiliki kualitas sangat diperlukan. SDM yang dimiliki oleh BJB Syariah KCP Kuningan baik dari segi perekrutan, penempatan sesuai kompetensi serta pembagian tugas dan jabatan serta pelaksanaan pengelolannya sudah sesuai SOP yang berlaku di perusahaan tersebut.

\section{2) Proses yang dilakukan bertahap}

Pengelolaan PPR sebenarnya dilakukan oleh pihak pusat dibawah divisi konsumer, adapun dalam hal ini pemasaran dilakukan oleh Cabang dan Kantor Cabang Pembantu. Bertahap disini yaitu dimulai dari proses awal pembangunan hingga penjualan pihak bank terlibat dalam segala kebijakan yang dikeluarkan, seperti dalam pemasaran adanya produk yang memang diperuntukan promo, serta kerja sama dengan beberapa pihak developer atau lembaga guna mencapai target yang ditentukan, dalam kerja sama seperti ini lembaga/developer mendapat keuntungan juga sesuai dengan kesepakatan yang telah ditentukan fee reveral.

\section{3) Kreatifitas dalam bekerja}

Dalam tahapan in kegiatan yang dilakukan oleh pihak BJB Syariah yaitu melakukan study banding terkait maintanance produk PPR/KPR kepada Bank lain, melihat pasar dan program kegiatan promo PPR. Ketika ada pihak developer yang memberikan nasabah (kerja sama) maka akan mendapatkan fee dari pihak bank karena dianggap mereka bagian dari marketing Bank.

Fungsi pengelolaan menjadi sangat penting dalam menunjang kesuksesan dari penjualan produk yang ditawarkan sehingga proses pengelolaan mendapatkan hasil yang baik, adapun fungsi pengelolaan produk yang sebaiknya diterapkan adalah :

Planning atau Perencanaan, perencanaan pengelolaan produk PPR di BJB Syariah KCP Kuningan dengan menggunakan target yang telah ditentukan atas kesepakatan yang sudah disepakati dan dipertimbangkan dengan baik. Dalam menentukan capaian atau target, 
tentunya mempertimbangkan beberapa aspek yang menunjang keberhasilan, pertama dalam perencanaan dilakukan dengan spesifik dan jelas terkait program dan waktunya, kedua yaitu realistis ini terkait Sumber daya manusia atau sumber daya organisasi yang dimiliki apakah bisa measurable atau tidak. Dalam perecanaan, perlu disusun strategi yang tepat pula untuk langkah dalam mencapai keberhasilan. Strategi disusun sesuai dengan target BJB Syariah KCP Kuningan yang akan dicapai pada kurun waktu tertentu.

Organizing (Pengorganisasian), aspek yang kedua yakni pengorganisasian atau pengelompokan terkait tugas dan tanggung jawab setiap divisi/jabatan yang ada, pada setiap jabatan yang ada memiliki peran fungsi dan tanggung jawab yang berbeda, semakin tinggi jabatan maka semakin besar pula risiko pengelolaan, tanggung jawab dan tugas yang diemban. Kerja sama yang dilakukan antara pegawai di BJB Syariah KCP Kuningan khususnya dalam pembiayaan PPR antara Sales, AO dan Analis menunjukan kerja sama yang baik dengan support pimpinan.

Actuating (Pergerakan), tahapan actuating, adalah bagaimana produk tersebut dikelola. Hal ini adalah berupa mengimplementasikan perencanaan mengenai pengelolaan produk PPR iB Maslahah di BJB Syariah KCP Kuningan. Tidak hanya itu, strategi juga berperan penting agar pergerakan atau aktivitas pengelolaan produk PPR bisa berjalan dengan optimal. Bahkan, jika dalam actuating yang merupakan perwujudan dari rencana sebelumnya ini bisa mencapai target, maka akan ada pemenuhan kebutuhan karyawan memberi penghargaan dan kompensasi atas target yang telah dicapai dari produk yang dipasarkan. Untuk hal ini BJB Syariah KCP Kuningan memberikan reward bagi karyawan yang mampu mencapai target atau melampui dari target bentuk apresiasi yang diberikan bisa berupa ucapan, kompensasi dan liburan.

Controlling (Pengawasan). Tahap pemeriksaan/pengawasan yang dilakukan oleh BJB Syaariah KCP Kuningan dalam produk memastikan semuanya sesuai dengan rencana yang ditetapkan biasanya dilakukan dengan pihak developer, ketika menemukan ketidak sesuain dari apa yang direncanakan dan di intrusikan, maka dilakukan tahap koreksi dan evaluasi atas kinerja yang telah dikerjakan. Apakah target produk PPR iB Maslahah dalam periode tersebut sudah tercapai atau sebaliknya. Hal tersebut dilakukan supaya target bisa tercapai dan merupakan bagian dari pengendalian risiko untuk meminimalisir risiko produk pembiayaan.

Bank BJB Syariah KCP Kuningan telah melaksanakan proses pengelolaan dengan baik, namun fungsi pengelolaan yang disebutkan diatas belum sepenuhnya diterapkan karena 
adanya kebijakan dari Kantor Pusat yang memegang otoritas mengenai pembagian pelaksanaan fungsi pengelolaan tersebut.

\section{SIMPULAN}

Dari penelitian yang penulis lakukan, dapat diambil kesimpulan bahwa Pembiayaan bahwa Prosedur Pembiayaan Pemillikan Rumah (PPR) pada dasarnya tidak begitu rumit, hanya harus melakukan prosedur yang telah ditetapkan oleh pihak Bank BJB Syariah KCP Kuningan, pihak Bank juga sudah menerapkan proses Manajemen Risiko yang sesuai dengan POJK seperti proses Identifikaasi Risiko, Pengukuran Risiko, Pemantauan Risiko dan Pengendalian Risiko. Setelah dirasa valid dan layak diberikan pembiayaan kemudian persetujuan pembiayaan dan tahap akhir yakni penagihan. Bank BJB Syariah KCP Kuningan juga telah menerapkan prinsip 5C, yaitu Character, Capacity, Capital, Condition of economy. Dalam proses pengelolaan produk, otoritas berada dipusat, sedangkan dalam melakukan pemasaran produk serta promo dan kerja sama dengan developer yang dilakukan menjadi tanggungjawab Bank terkait (Bank Kantor Cabang dan Kantor Cabang Pembantu). Proses pengelolaan yang dilakukan Bank BJB Syariah KCP Kuningan yakni dimulai dari pengelolaan Sumber daya organisasi yang baik, proses bertahap dan melakukan kreatifitas, namun dalam pengelolaan, penerapannya perlu otoritas dari pusat.

\section{REFERENSI}

Ayus Ahmad, Yusuf. (2009). Manajemen Operasional Bank Syariah.Cirebon : STAIN Press Antonio, Muhammad Syafii. (2011). Bank Syariah dari Teori ke Publik. Depok : Gema Insani

Ascaryadi. (2008). Akad dan Produk Bank Syariah.Jakarta : Rajawali Pers

Arikutama,Suharismi. (1998). Pengelolaan Kelas dan Siswa.Jakarta : Rajawali

BJB Syariah. 2018 Bank BJB Syariah. Diambil kembali dari http://www.bjbsyariah.co.id/pemilikan-rumah

Fatwa DSN No : 04/DSN-MUI/MUI/IV/2000 Tentang Pembiayaan

Fahmi, Irham. (2014) Manajemen Perkreditan .Bandung : Alfabeta

Hakim, Lukman. (2012). Prinsip-Prinsip Ekonomi Islam, Yogyakarta : Erlangga

Imam Wahyudi, Miranti Kartika dan Fenny Rosmanita. (2013). Manajemen Risiko Bank Islam. Jakarta : Salemba empat

Indorse, Fery. (2008). Manajemen Risiko Perbankan, Pemahaman 3 Pilar Kesepakatan Basel II Terkait Aplikasi Regulasi dan Pelaksanaanya di Indonesia.Depok : Rajawali Pers

Ismanudin, Fakhri. (2015) Analisis Pengelolaan produk Deposito Mudharabah, Studi kasus Bank BNI Syariah Fatmawati .Jakarta

Karim, Adiwarman. (2011). Bank Islam Analisis Fiqh dan Keuangan.Jakarta : Rajawali Pers

Kasmir. (2002). Dasar-Dasar Perbankan. Jakarta : Raja Grafindo Persada 
Murtoyo,Susilo S.E. (1998). Pengetahuan Dasar Manajemen dan Kepemimpinan. Yogyakarta : BPFE

Kiat Cerdas, Bijak Memahami Masalah Akad Syariah. Bandung : Mizan Pustaka

Pemerintah Republik Indonesia. Undang-undang Republik Indonesia Nomor 1

Tahun 2013 tentang Lembaga Keuangan Mikro. Jakarta : Sekretariat Negara

Rachmat, Ariyanti, (2003). Manajemen Perkreditan Bank Umum. Bandung : Alfabeta

Sugiyono. (2017). Metode Penelitian Kuantitatif Kualitatif dan R\&D. Bandung : Alfabeta

Sujarweni, Wiratna. (2014) Metodologi Penelitian.Yogyakarta : Pustaka Baru Press

Sule, Erni Trisnawati,Kurniawan dan Saefullah. (2009). Pengertian Manajemen. Jakarta : Kencana Perdana Media

Safiri Sofyan. (1996). Manajemen Kontemporer.Jakarta : Raja Grafindo Persada

Veitzhal Rivai, Rifki Ismail. (2013). Islamic Risk Management For Islamic Bank. Jakarta : Gramedia Pustaka Utama

Yusuf Muhammad. Analisis Peranan Pembiayaan Murabahah Berdasarkan Pesanan dan Tanpa Pesanan Serta Kesesuaian PSAK 102 Volume 4 No 1. Jakarta : BINUS University

Kamus Besar Bahasa Indonesia (KBBI) Online. Diakses melalui https://kbbi.kemdikbud.go.id/entri/wawancara-produk, 21 Januari 2021 